\title{
Ecological Diversity of Medicinal Plants and Conservation by the Tribes of Shahdol District with Special References of Barleriaacanthoides Vahl.
}

\author{
Nidhi Upadhayay \\ Department of Botany, Pt. S.N.S. Govt. P.G. College, Shahdol - 484001, India
}

\begin{abstract}
The present paper deals with 30 plants species which are conserved by the tribes of district Shahdol, Madhya Pradesh, India. Due to destruction of habitat, biotic interference and indiscriminate exploitation of natural plants, many valuable plant species of this area are fast disappearing.
\end{abstract}

Keywords: Ecological Diversity, Plant Conservation, Tribes, Shahdol, Barleriaacanthoides Vahl.

\section{Introduction}

Shahdol district is north eastern part of Madhya Pradesh state. It is lying between $23^{0} 17^{\prime} 47^{\prime \prime} \mathrm{N}$ latitude and $81^{0} 21^{\prime 2} 21^{\prime \prime}$ E longitude. Total geographical area sums up to $5671 \mathrm{sq} . / \mathrm{Km}$. and has a population of 908148 . Shahdol is riched in vast resources of forest and minerals. It is bounded in the north by Satna and Sidhi district, in the east by Korea district, in the south by Anuppur district, in the west by Umaria district. The area is full of water springs which come out on the top hill slopes. The Shahdol district is average rainfall is $85.11 \%$ and above temperature 13.6 ${ }^{0} \mathrm{C}$. The tribes living in some villages situated in and around Shahdol district. They depend solely on their surrounding forest for most of their requirement for food to medicines. (Figure 1).

The area of Shahdol district is inhabited by a large section of tribal population. The highest tribal population, exits in this tract, totally or partially, depends upon natural vegetation for the necessities of life, including remedies for several diseases. Some of these have a supernatural basis to the tribal mind, while others are recognised as physical and attempts are made to treat them. They usually collect their materials from nearby forests and use them in their health care system, which is well developed and proven successfully for generation together.

Several tribalsas Gond, Kondar, Kol, Baiga, Bharia, etc. are maintaining their culture and traditions since these cultures are influenced by scientific and economic changes, it is therefore, essential to study and conserve them before they become extinct. Madhya Pradesh still has the aboriginal tribals living in the forest as well as in the remote villages inhabited by so called higher castes. Since they are distributed mostly in the areas previously occupied by thick forest, they have learnt to use these habitats better for their living.

A survey of literature indicates that Dwivedi (2003), Jain (1963, 1997), Khare (2001), Prajapati and Khare (2004), Saxena and Tripathi (1989, 1990), Shah and Singh (1990) and Singh et al (2004) have made important contribution in this field. The tribals do not have any well defined conservation strategy of the kind we understand in modern terms. But they do conserve plants that are medicinally, economically, socially and culturally significant to them. Their mode of conservation depends on faith and tradition.

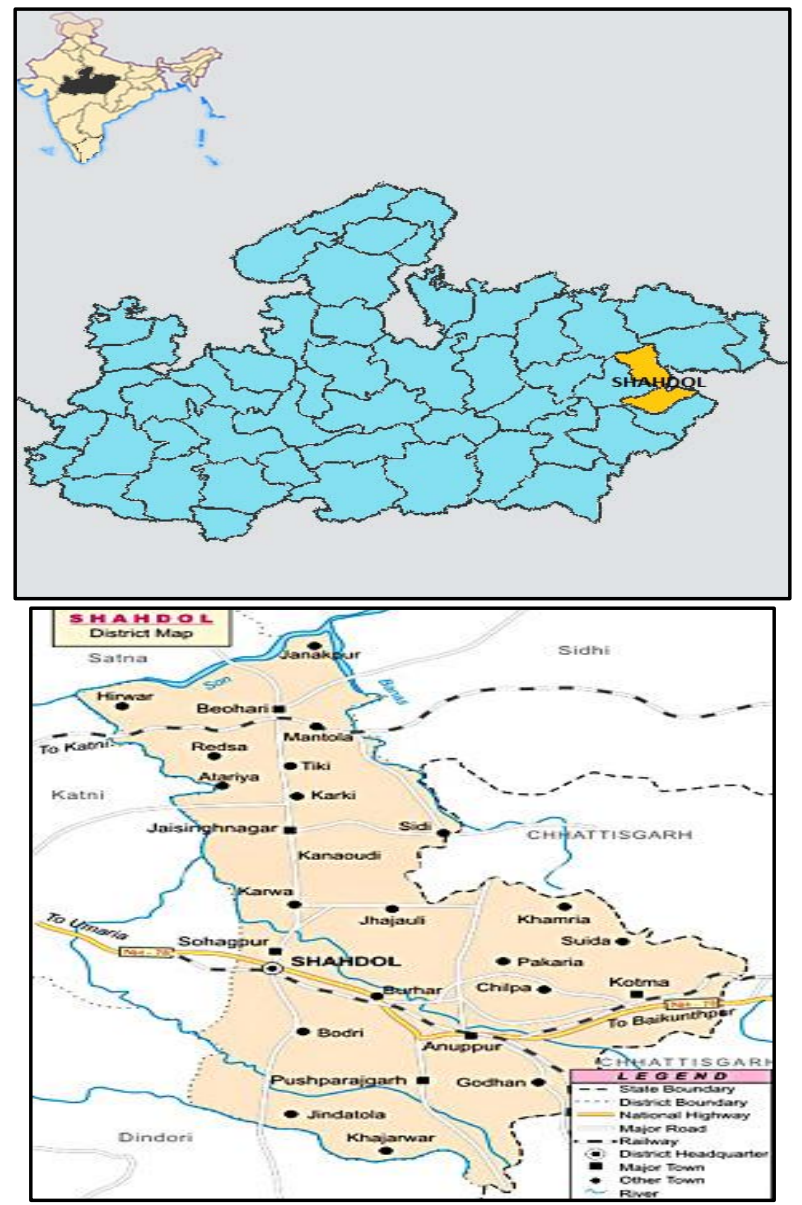

Figure 1: Location Map of Madhya Pradesh and study site of District Shahdol

\section{Material and Methods}

For the ethnobotanical study plant human interaction has to be observed carefully in the dynamic ecosystem in which they exist. The plants were collected by the investigator from the different study sites of Shahdol district during 2011 -2012 by extensive field work. The queries were made as per plan suggested by Agrawal 


\section{International Journal of Science and Research (IJSR) \\ ISSN (Online): 2319-7064 \\ Index Copernicus Value (2013): 6.14 | Impact Factor (2015): 6.391}

(1983), Jain and Goel (1987) and the preservation methods were followed as prescribed by Agrawal(1983), Khan et. al (2008), Ahirwar (2011) and Raizada (1984).

Table 1: Ecological Diversity of Medicinal Plants Conservation by the Tribes of Shahdol forest area

\begin{tabular}{|c|c|c|c|c|}
\hline S. No. & Plant Name ( Local Name ) & Family & $\begin{array}{l}\text { Plant part } \\
\text { uses }\end{array}$ & Reason for Conservations \\
\hline 1. & Achyranthusaspera L.(Chirchita) & Amaranthaceae & $\begin{array}{l}\text { Root and } \\
\text { leaves }\end{array}$ & $\begin{array}{l}\text { Roots are leaves are used in } \\
\text { medicine. }\end{array}$ \\
\hline 2. & $\begin{array}{l}\text { Adina cordifoliaBenth.\& Hook } \\
\text { (Haldu) }\end{array}$ & Rubiaceae & Wood & $\begin{array}{l}\text { The wood is considered } \\
\text { auspicious. }\end{array}$ \\
\hline 3. & Aegle marmelos (L.) Corr.(Bel) & Rutaceae & Leaf & $\begin{array}{l}\text { Sacred plant, the leaves are used } \\
\text { to worship' Lord Shiva'. }\end{array}$ \\
\hline 4. & Annona squamosa (Sitaphal) & Annonaceae & Fruit, seed & For fruits and medicine. \\
\hline 5. & $\begin{array}{l}\text { Anthocephaluschinensis } \\
\text { (Lamk.)Rich.(Kadam). }\end{array}$ & Rubiaceae & Whole plant & Sacred plant, fruits are edible. \\
\hline 6. & AzadirachtaindicaJuss.(Neem) & Meliaceae & Leaf & $\begin{array}{l}\text { Plant is an abode of 'Marhi Mata' } \\
\text { (The Goddess of small pox) } \\
\text { Leaves are used in medicines and } \\
\text { pest control. }\end{array}$ \\
\hline 7. & BarleriaacanthoidesVahl. & Acanthaceae & Whole Plant & $\begin{array}{l}\text { An annual or perennial herb. Its } \\
\text { decoction is used in cold as well } \\
\text { as malarial fevers. }\end{array}$ \\
\hline 8. & Buchananialanzan Spr.(Char) & Anacardiaceae & $\begin{array}{l}\text { Fruits and } \\
\text { seeds }\end{array}$ & For fruits and seeds. \\
\hline 9. & $\begin{array}{l}\text { Butea monosperma (Lamk.) Taub. } \\
\text { (Palas) }\end{array}$ & Papilionaceae & $\begin{array}{l}\text { Leaves and } \\
\text { flowers }\end{array}$ & $\begin{array}{l}\text { Leaves are used for thatches, and } \\
\text { the flowers are used to worship } \\
\text { 'Lord Jagannath. }\end{array}$ \\
\hline 10. & Calotropisprocera Br.(Madar) & Asclepiadaceae & $\begin{array}{l}\text { Flowers and } \\
\text { fruits }\end{array}$ & $\begin{array}{l}\text { The flowers and fruits are used to } \\
\text { worship 'Lord Shiva'. }\end{array}$ \\
\hline 11. & ErythrinasuberosaRoxb.(Handua) & Papilionaceae & Wood & $\begin{array}{l}\text { The wood is considered } \\
\text { auspicious for wedding place. }\end{array}$ \\
\hline 12. & Ficusbengalenis L.(Bar) & Moraceae & Whole plant & $\begin{array}{l}\text { Sacred plant worshiped on 'Bara } \\
\text { Barsat' festival. }\end{array}$ \\
\hline 13. & Ficusreligiosa L.(Pipal) & Moraceae & Whole plant & $\begin{array}{l}\text { The plant is considered on abode } \\
\text { of 'Barsat 'festival. }\end{array}$ \\
\hline 14. & $\begin{array}{l}\text { Gymnemasylevestre( Retz.) } \\
\text { R.Br.(Gurmar) }\end{array}$ & Asclepiadaceae & Leaf & The leaves are used in medicine. \\
\hline 15. & $\begin{array}{l}\text { Holarrhenaantidysenterica } \\
\text { Wall.(Dudhi) }\end{array}$ & Apocynaceae & Bark & The bark is used for medicine. \\
\hline 16. & $\begin{array}{l}\text { Holopteleaintergrifolia } \\
\text { (Roxb.)Planch.(Chirol) }\end{array}$ & Ulmaceae & $\begin{array}{l}\text { Leaf and } \\
\text { Bark }\end{array}$ & $\begin{array}{l}\text { Leaves are used as fish poison } \\
\text { and bark is used in medicine. }\end{array}$ \\
\hline 17. & Lawsoniainermis L. (Menhdi) & Lythraceae & Leaf & The leaves are used for dye. \\
\hline 18. & $\begin{array}{l}\text { Madhucalongifolia (Koen.)Mac. } \\
\text { Br.(Mahua) }\end{array}$ & Sapotaceae & Whole plant & $\begin{array}{l}\text { Sacred plant, flowers used for } \\
\text { liquor, and the wood is } \\
\text { considered auspicious. }\end{array}$ \\
\hline 19. & Mangiferaindica L.(Aam) & Anacardiaceae & Whole plant & $\begin{array}{l}\text { For wood, leaves and fruits. The } \\
\text { inflorences are offered to 'Lord } \\
\text { Shiva' at Mahashivratri festival. }\end{array}$ \\
\hline 20. & Ocimum sanctum L. (Tulsi) & Lamiaceae & Whole plant & $\begin{array}{l}\text { Sacred plant, worshiped by girls } \\
\text { for good groom. }\end{array}$ \\
\hline 21. & Phoenix sylvestrisRoxb. (Khajri) & Araceae & Leaf, fruit & $\begin{array}{l}\text { The fruits are edible and leaves } \\
\text { are used to make headgear and } \\
\text { brooms. }\end{array}$ \\
\hline 22. & Emblicaofficinalis L.(Amla) & Euphorbiaceae & Whole plant & $\begin{array}{l}\text { Sacred plant, worshipped on } \\
\text { 'Akshaya Navmi', fruits are eaten } \\
\text { and used in medicine. }\end{array}$ \\
\hline 23. & SterculiaurensRoxb.(Kullu) & Sterculiaceae & Whole plant & $\begin{array}{l}\text { The plant is conserved for gum, } \\
\text { wood and medicine use. }\end{array}$ \\
\hline 24. & SterculiavillosaRoxb.(Udar) & Sterculiaceae & Root & The root is taken as a medicine. \\
\hline 25. & Syzygiumcuminii (L) Skeels.(Jamun) & Myrtaceae & Fruits & Fruits are edible. \\
\hline 26. & $\begin{array}{l}\text { Terminalia arjuna (Roxb.ex. } \\
\text { DC.)Wt. \&Arn. (Kahwa) }\end{array}$ & Combretaceae & Whole plant & $\begin{array}{l}\text { Sacred plant, bark is used in } \\
\text { medicine. }\end{array}$ \\
\hline 27. & $\begin{array}{l}\text { Terminalia bellerica (Gaertn.) } \\
\text { Roxb.(Bahera) }\end{array}$ & Combretaceae & Fruits & $\begin{array}{l}\text { The fruits are eaten with of Amla } \\
\text { as a medicine. }\end{array}$ \\
\hline 28. & Terminalia chebula Retz.(Harra) & Combretaceae & Fruits & Roasted fruits are eaten as a \\
\hline
\end{tabular}




\section{International Journal of Science and Research (IJSR) ISSN (Online): 2319-7064}

Index Copernicus Value (2013): 6.14 | Impact Factor (2015): 6.391

\begin{tabular}{|c|l|c|c|l|}
\hline & & & & medicine. \\
\hline 29. & $\begin{array}{l}\text { Terminalia tomentosa } \\
\text { Wt.\& Arm (Saja) }\end{array}$ & Combretaceae & Whole plant & $\begin{array}{l}\text { Sacred plant, dwelling place of } \\
\text { 'Bara Dev'. }\end{array}$ \\
\hline 30. & $\begin{array}{l}\text { Woodfordiafruiticosa (L.) Kurz. } \\
\text { (Dhwai) }\end{array}$ & Lythraceae & Flowers & Flowers used in medicine. \\
\hline
\end{tabular}

\section{Results and Discussion}

Present study period is reported with 30 plant species, which are conserved by the tribes of Shahdol district forest area for obvious reasons. These Tribes organise various occasions and worship plants time to propitiate their gods and goddess.
These traditions encouraged us to know their beliefs and ethnobotanical importance behind it. The botanical names of plants are alphabetically arranged, followed by their local name. All the data obtained as a sequence of Barleriaacanthoides Vahl. Present study has been reported (Table 1-2 and Figure 2).

Table 2: IVI of Medicinal plants in Shahdol Forest Community

\begin{tabular}{|c|c|c|}
\hline S. No. & Botanical Name of species & IVI \\
\hline 1. & Achyranthusaspera L.(Chirchita) & 99.785 \\
\hline 2. & Adina cordifoliaBenth.\& Hook (Haldu) & 19.725 \\
\hline 3. & Aegle marmelos (L.) Corr.(Bel) & 19.291 \\
\hline 4. & Annona squamosa (Sitaphal) & 16.893 \\
\hline 5. & Anthocephaluschinensis (Lamk. )Rich.(Kadam). & 14.780 \\
\hline 6. & AzadirachtaindicaJuss.(Neem) & 9.119 \\
\hline 7. & BarleriaacanthoidesVahl. & 8.247 \\
\hline 8. & Buchananialanzan Spr.(Char) & 7.639 \\
\hline 9. & Butea monosperma (Lamk.) Taub. (Palas) & 7.494 \\
\hline 10. & Calotropisprocera Br.(Madar) & 6.663 \\
\hline 11. & ErythrinasuberosaRoxb.(Handua) & 6.178 \\
\hline 12. & Ficusbengalenis L.(Bar) & 6.160 \\
\hline 13. & Ficusreligiosa L. (Pipal) & 5.668 \\
\hline 14. & Gymnemasylevestre( Retz.) R.Br.( Gurmar) & 5.173 \\
\hline 15. & Holarrhenaantidysenterica Wall. ( Dudhi) & 5.094 \\
\hline 16. & Holopteleaintergrifolia (Roxb.)Planch.(Chirol) & 5.088 \\
\hline 17. & Lawsoniainermis L. (Menhdi) & 4.708 \\
\hline 18. & Madhucalongifolia (Koen.)Mac. Br.(Mahua) & 4.514 \\
\hline 19. & Mangiferaindica L.(Aam) & 4.466 \\
\hline 20. & Ocimum sanctum L. (Tulsi) & 4.411 \\
\hline 21. & Phoenix sylvestrisRoxb. (Khajri) & 4.229 \\
\hline 22. & Emblicaofficinalis L. (Amla) & 3.893 \\
\hline 23. & SterculiaurensRoxb.(Kullu) & 2.973 \\
\hline 24. & SterculiavillosaRoxb.(Udar) & 2.188 \\
\hline 25. & Syzygiumcuminii (L) Skeels.(Jamun) & 2.057 \\
\hline 26. & Terminalia arjuna (Roxb.ex. DC.) Wt. \&Arn. (Kahwa) & 2.045 \\
\hline 27. & Terminalia bellerica (Gaertn.) Roxb.(Bahera) & 2.036 \\
\hline 28. & Terminalia chebula Retz.(Harra) & 2.000 \\
\hline 29. & $\begin{array}{l}\text { Terminalia tomentosa } \\
\text { Wt.\& Arm(Saja) } \\
\end{array}$ & 1.976 \\
\hline 30. & Woodfordiafruiticosa (L.) Kurz.(Dhwai) & 1.777 \\
\hline
\end{tabular}

Graph 1: IVI of Medicinal plants in Shahdol Forest area

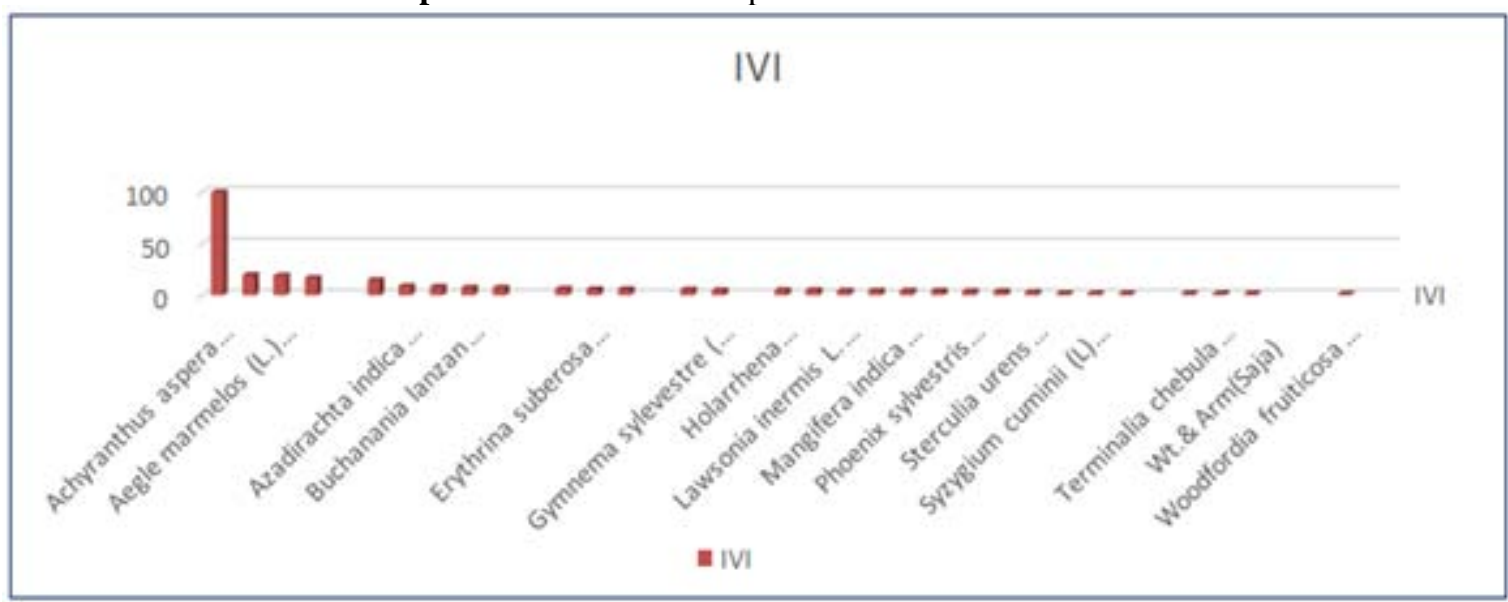

Volume 5 Issue 4, April 2016 www.ijsr.net 


\section{Acknowledgement}

The authors are thankful to Tribal of this District in providing information about the plant species conserved by them. We express our gratitude to the Principal of Govt. P.G. College, Shahdol (M.P.) for helpful suggestions and encouragement.

\section{References}

[1] Agrawal, V. S. (1983). Perspective in Botanical Museum with species reference to India. Today and Tomorrow, New Delhi.

[2] Ahirwar, R.K. "Ethno medicinal plants studies in Jaitpur Forest Range of Shahdol District, Central India." Ad. plantSci 24 (2011): 681-684.

[3] Ahirwar, Ramesh Kumar and Girja, Kumar Singh (2011) Someanti diabetic plants from Dindori District of Madhya Pradesh (India). Ind. J. Appl. pure Bio.26 (2) 269-271.

[4] Dwivedi, S.N.(2003). Etgnobotanical studies and conservational strategies of wild and natural resources of Rewa district of Madhya Pradesh, J.Econ. Taxon. Bot..27.

[5] Jain, S.K.(1963), Observations on ethnobotany of the tribals of Madhya Pradesh. Vanyajati11 (4): 177-183.

[6] Jain, S.K. and A.K. Goel(1987). Problem for field work. P. 171-183. In manual of ehthnobotany. Ed. S.K. Jain, Scientific publisher (India) Jodhpur.

[7] Khare, R.K. (2001) Study of ethnobotany among the tribals of Panna district with species reference to biodiversity. Ph. D. Thesis A.P.S. Univ. Rewa (M.P.)

[8] Khan.A.A, Agnihotri, S.K, Singh M.K \& Ahirwar, R.K. 2008. Enumaration of certain Angiospermic plants used by Baiga tribe for Conservations of Plants Species. Plant Archives 8. (I) 289-291.

[9] Prajapati, P.L. and P.K. Khare (2004). Medicinal plants used by tribals of Panna district Madhya Pradesh (India) Plant Archives.4:113-115.

[10] Raizada, A., 1984. Tribal Development of Madhya Pradesh - A planning perspective, Inter - India Publication, New Delhi, pp. 1-220 